\title{
Online Learning PBL Model with the STS Approach to Improve High School Students' Critical Thinking Ability
}

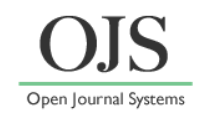

\author{
Gita Lorencia S.", Budi Jatmiko \\ Jurusan Fisika, Fakultas Matematika dan Ilmu Pengetahuan Alam, Universitas Negeri Surabaya \\ *Email: gita.17030184055@mhs.unes.ac.id
}

DOI: https://doi.org/10.33369/pendipa.5.3.459-465

\begin{abstract}
The research aims to describe the effectiveness of online learning using PBL (Problem Based Learning) model with STS (Science Technology Society) approach to improve students' critical thinking ability. This research was Pre experimental with pre-test and post-test design conducted at Lab-school UNESA High School in the academic year 2020/2021. The research sample consisted of 56 students of eleventh grade Natural Science. Collecting data is done through pre-test, applying the model PBL with the STS approach through the Google meet, and the last is post-test. Analysis data using paired t-test, analysis of n-gain, and independent $t$-test. According to analysis data, students' critical thinking ability scores are suffering an increase that is significant at $\alpha=5 \%$ with an average $n$-gain in the medium category and consistent in both classes. The conclusion is that the online learning PBL model with the STS approach effectively improves the critical thinking ability of high school students.
\end{abstract}

Keywords: Online Learning, PBL, STS, Critical Thinking.

\begin{abstract}
ABSTRAK
Penelitian ini bertujuan untuk mendeskripsikan keefektifan pembelajaran daring model PBL (Problem Based Learning) dengan pendekatan STM (Science Teknologi Masyarakat) dalam meningkatkan kemampuan berpikir kritis siswa. Penelitian ini merupakan penelitian Pre Eksperimental dengan desain pre-test dan post-test yang dilaksanakan di SMA Labschool UNESA tahun ajaran 2020/2021. Sampel penelitian terdiri dari 56 siswa kelas XI IPA. Pengumpulan data dilakukan melalui pre-test, menerapkan model PBL dengan pendekatan STM melalui Google meet, dan yang terakhir adalah post-test. Analisis data dilakukan dengan menggunakan uji t berpasangan, analisis n-gain, dan uji t independen. Berdasarkan data analisis, skor kemampuan berpikir kritis siswa mengalami peningkatan yang signifikan pada $\alpha=5 \%$ dengan rata-rata n-gain pada kategori sedang dan konsisten pada kedua kelas. Kesimpulannya adalah pembelajaran online model PBL dengan pendekatan STM ternyata meningkatkan kemampuan berpikir kritis siswa SMA.
\end{abstract}

Kata kunci: Pembelajaran Daring, PBL, STM, Berpikir Kritis. 


\section{INTRODUCTION}

The development of technology demands of society has the ability of $21^{\text {st }}$ century. The ability of the $21^{\text {st }}$ century are needed in learning, communication, media, dan technology (TJ Syarifah, B Usodo, \& Riyadi, 2019).The ability demands of society to have the critical thinking ability, problem-solving and communication. Education is a field that requires the ability of the $21^{\text {st }}$ century, such as the achievement of competence $4 \mathrm{C}$, namely: critical, creative, collaboration, and communication. Besides that, with the ability of $21^{\text {st }}$ century demanding field of education, especially those for force educators to have competence in these to students' teaching ability (Rusmansyah, et al., 2020). All educators have to guide students to achieve that competency through education. It mentioned that Science and Technology are rapidly potentially changing lives (Risnanosanti, Susyla, \& Syofiana, Developing Students Critical Thinking Ability Through Lesson Study, 2019). Adapting $21^{\text {st }}$ century ability through education is an important action to anticipate changes in society's dynamic (D H Putri, Risdianto, \& Sutarno, 2017). With those ability, then person is ready to endure their life in the face of change. One of the important capabilities is critical thinking ability. The critical thinking ability is essential in the process of problem-solving. But the state of critical thinking in Indonesia is still relatively low. According to the Program for International Student Assessment results, Indonesian's ranking in the category of Science is 62 of the 71 countries. The results are indicating that students in Indonesia still has shortcoming in the process of learning the category of Science, especially in the thinking ability that more low than other countries. The results are also supported by research Puspita (2019). From the results of interviews with teachers of physics discovered the fact that the understanding of the students related to the concept of physics is low.

Indonesia is one of the countries affected by coronavirus diseases pandemic.
According to ministries' decision in the guide to the organization of learning in the academic 2020/2021, in the pandemic time learning in all institutions of education to do it online. However, according to Noven (2020), online learning still has obstacles, especially for schools0 without a Learning Management System. The disadvantages of online learning include the lack of interaction between teacher and students. Because it's educators, tasked for making the process of knowledge that can improve the interaction and goal achievement of $21^{\text {st }}$ century competence, such as the critical thinking ability can be achieved. According to Haris Iskandar, as the Acting DirectorGeneral of Dikdasmen Kemendikbud, educators are not to be riveted online learning and the provision of duty but is expected to educators to be able to explore the activities for giving students' motivation, especially because of the limitations of the technology, based on the demands of adaptation ability of $21^{\text {st }}$ century and constrains were experienced when online learning, then takes the application of the model of learning that is effective to improve the students critical thinking ability in online learning.

Solution alternatives in online learning to improve students' critical thinking ability are using a model of PBL by using the STS approach. Based curriculum that is implemented in Indonesia, namely "Kurikulum 2013 revisi", stating there are four learning models is advised to use in learning, one of which is a model of PBL. PBL model is a model of education that has the stage to guide students in finding the solution of a problem independently to motivate students and to explore the problem-solving ability and critical thinking ability (Kurniasih, Imas, \& Berlin, 2015). Through PBL, students could learn the analytical thinking and solve the problem. (I B Nasution, W Liliawati, \& L Hasanah, 2019). Because it's, PBL can help students developed their cognitive thinking and meaningfulness of knowledge acquired.

In general, the learning of physics that uses models and methods conventionally impacts students' lack of activity. By 
because it is according to Aweke (2017), PBL model can increase the students' motivation in the process of learning physics because when students are faced with a problem, students will attempt to investigate the problems and seek settlement of the problem while training settlement issue, analytical and critical thinking. Approaches that suit it be combined with the PBL model is STS (Science Technology Society). National Science Teacher Association defines STS as a learning model that links technology and science. The study earlier conducted by Muhibbudin (2019), finding that using the approach of STS can improve the students' critical thinking ability.

Based on the description of the theory and the study results earlier, the research on the application of the model and approach to learning online are effective for improving students' critical thinking ability needs to do more advanced. In previous research, the application of learning models and approaches was carried out face-to-face. Because it was conducted, this research aims to describe the effectiveness of the model of Problem Based Learning with the Science Technology Society to improve students' critical think ability.

\section{RESEARCH METHODS}

This research is a Pre-Experimental study with a pre-test and post-test design. The research design is described in Table 1:

Table 1. Research Design

\begin{tabular}{cccc}
\hline Class & $\begin{array}{c}\text { Pre- } \\
\text { test }\end{array}$ & Treatment & $\begin{array}{c}\text { Post- } \\
\text { test }\end{array}$ \\
\hline XI 1 & $\mathrm{U}_{1}$ & $\mathrm{~L}$ & $\mathrm{U}_{2}$ \\
XI 2 & $\mathrm{U}_{1}$ & $\mathrm{~L}$ & $\mathrm{U}_{2}$ \\
\hline
\end{tabular}

Remarks :

$\mathrm{U}_{1}:$ Pre-test (initial test before treatment)

L :Online learning PBL model with STS approach on Global Warming.

$\mathrm{U}_{2}$ : Post-test (final test after treatment)

This research was conducted in the even semester of 2020/2021 academic year. The population of this study were eleventh grade of Labschool UNESA High School Surabaya. The research sample was students of eleventh grade Natural Science 1 and eleventh grade Natural Science 2 in the 2021/2021 academic year. Data was obtained by giving pre-test and post-test based on indicators of critical thinking ability in the Global Warming material. Tests in research are using four indicators that interpretation, analysis, inference, and evaluation.

The research instrument was validated by two expert lecturers of the Department of Physics, State University of Surabaya. The data analysis of the results of the validation of the research instrument was carried out by looking for the average score of each device and categorizing the validity criteria. The data obtained from the pre-test and post-test scores were tested for prerequisites, namely the normality test and the homogeneity test. Once it is in the paired t-test to know the differences in the results of the pre-test and post-test and analyzed by an average n-gain to investigate an increase in the students' critical thinking ability in each class. Then the gain of two classes was testes using the independent $t$-test to determine the consistency of the increase in the scores of the two classes. The PBL model with STS approach is said to be effective if the increase in the critical thinking is significant at $\alpha=5 \%$, with an average $n$-gain minimal category medium and consistent in both classes.

\section{RESULTS AND DISCUSSION}

Before conducting the research, instrument validation was carried out by two expert lecturers of the Department of Physics, State University of Surabaya. The purpose of instrument validation is to determine the instrument validity criteria. Use-values validity instrument is shown in Table 2:

Table 2. Instrument Validity Values

\begin{tabular}{ccc}
\hline $\begin{array}{c}\text { Research } \\
\text { Aspects }\end{array}$ & $\begin{array}{c}\text { Average } \\
\text { Value }\end{array}$ & Criteria \\
\hline Sylabus & 3,7 & Very valid \\
RPP & 3,5 & Very valid \\
LKPD & 3,4 & Valid \\
Handout & 3,4 & Valid \\
\hline
\end{tabular}


Based on Table 2, it can be known that the average score of the syllabus and RPP research aspects is in the range of 3.5-4.0 so that it meets the very valid criteria. While the research aspects of LKPD and Handout have an average score in the field of 3.0-3.4, it meets the valid criteria because the instrument is declared feasible to be used.

To determine the increase in students' critical thinking in both classes, do paired ttest. Before doing paired t-test, test perquisite up in advance to determine whether a data already distributed normally with homogeneous population. The results test of normality is obtained in Table 3:

Table 3. Normality Test Results

\begin{tabular}{ccccc}
\hline \multirow{3}{*}{ Class } & $\boldsymbol{X}^{2}$ & \multicolumn{2}{c}{$\boldsymbol{X}^{2}$ count } & Information \\
\cline { 3 - 4 } & table & $\begin{array}{c}\text { Pre- } \\
\text { test }\end{array}$ & $\begin{array}{c}\text { Post- } \\
\text { test }\end{array}$ & $\begin{array}{c}\text { of } \\
\text { distribution }\end{array}$ \\
XI 1 & & 1,7 & 1,9 & \\
XI 2 & 11,1 & 2,7 & 10, & Normal \\
& & & 8 & \\
\hline
\end{tabular}

The normality test in this study used the chisquare test. If $X_{\text {count }}^{2}<X^{2}$ table, it means that the data obtained is normally distributed. Based on Table 3, it can be observed that the pre-test and post-test data in both classes are normally distributed. The results test of homogeneity is obtained in Table 4:

Table 4. Homogeneity Test Results

\begin{tabular}{|c|c|c|c|}
\hline & & $X_{\text {count }}^{2}$ & \\
\hline Class & $X^{2}$ table & $\begin{array}{c}\text { Pre- Post } \\
\text { test -test }\end{array}$ & Information \\
\hline $\begin{array}{l}\text { XI } 1 \\
\text { XI } 2\end{array}$ & 11,1 & 0,1 & Homogenous \\
\hline
\end{tabular}

According to Table 4, it can be observed that the value of the probability of the data pretest is 0.1 , and post-test is 0.5 . Because of the value $X_{\text {count }}^{2}<X_{\text {table, }}^{2}$ then it means that the sample comes from a population that is homogeneous.

After the prerequisite test is fulfilled, the paired t-test is carried out.

If the value of $t_{\text {count }}>t_{\text {table }}$ means $\mathrm{H}_{0}$ is rejected and $\mathrm{H}_{1}$ accepted, it means that the online learning PBL model with STS approach affects the improvement of critical thinking ability. Results paired t-test in obtained as follows in Table 5:

Table 5. Paired t-test Results

\begin{tabular}{lccc}
\hline Class & $\mathbf{t}_{\text {table }}$ & $\mathbf{t}_{\text {count }}$ & Information \\
XI 1 & 2,051 & 2,070 & \\
XI 2 & & 3,378 & $\mathrm{H}_{0}$ rejected \\
\hline
\end{tabular}

Based on "Table 5", it can be observed that $t_{\text {count }}>t_{\text {table }}$ in both classes with a significance level of 0,05 . It means $\mathrm{H}_{0}$ rejected and $\mathrm{H}_{1}$ accepted, then it can be said that the value of the post-test is higher that the value of the pre-test.

To know the criteria for increase in the students' critical thinking ability, then analyze n-gain. Result analysis of n-gain in the gain as follows:

Table 6. Results of n-gain analysis

\begin{tabular}{lll}
\hline Class & $\langle$ g $>$ & Category \\
XI 1 & 0,57 & Medium \\
XI 2 & 0,58 & Medium \\
\hline
\end{tabular}

Based on Table 6, it can be observed that the case increase the students' critical thinking ability in both classes with a value of 0,57 and 0,58 in the medium category. The chart of the pre-test, post-test and n-gain mean values is obtained in Figure 1 below:

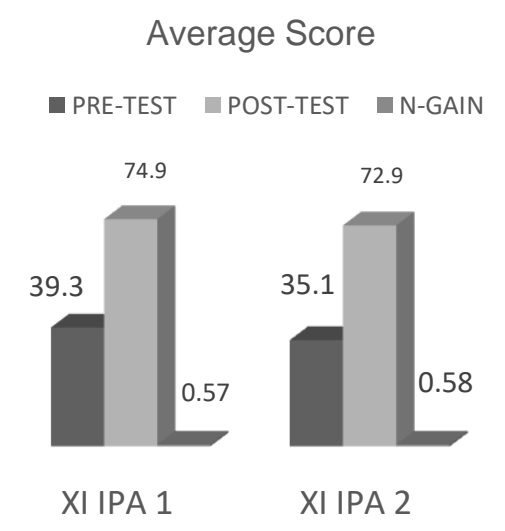

Figure 1. Average score of pre-test, posttest, and $n$-gain.

In Figure 1, it can be observed that the posttest mean in both classes is greater than the 
pre-test average. In both classes have an average of n-gain in the range of $0.3-0.7$.

Furthermore, to determine the consistency of both classes' mean scores, an independent t-test was carried out.

If $t_{\text {count }}<t_{\text {table }}$ means that there is no difference in the average n-gain score of the both classes so that $\mathrm{H}_{0}$ accepted and $\mathrm{H}_{1}$ rejected, there is consistency in improving students' critical thinking ability. The results of the independent $\mathrm{t}$-test are shown in Table 7:

Table 7. Independent t-test Results

\begin{tabular}{lccc}
\hline Class & $\mathbf{t}_{\text {table }}$ & $\mathbf{t}_{\text {count }}$ & Information \\
XI 1 & 1,70 & 0,839 & $\mathrm{H}_{0}$ accepted \\
XI 2 & 3 & & \\
\hline
\end{tabular}

Based on Table 7, it can be observed that the research results show $t_{\text {count }}<t_{\text {table }}$ so that $\mathrm{H}_{0}$ is accepted. Because it concluded that happens consistency increases students' critical thinking ability through online learning PBL model with STS approach.

Based on the results of the data analysis that has been obtained, in "Figure 1" it can be observed that the pre-test value before being given the online learning PBL model with STS approach is lower than the posttest score after being given the online learning PBL model with STS approach in both classes. According to value of the average pre-test are obtained by the students still below the value of 50 can be said the students have not been able to resolve the matter of indicators of the critical thinking ability. Indicators of the critical thinking ability are used in the interpretation, analysis, evaluation, and inference. Online learning that is applied in the research is to direct students to think critically using PBL with STS approach. Students are given problems associated with the activities and the use of technology, the cause of global warming in daily life.

Based on results of paired t-test in Table 5, we can say that online learning PBL model with STS approach can improve the high school students' critical thinking ability in the material Global Warming. In addition to the results of the analysis of n-gain in
Table 6, it can be said that in both classes occur, increasing the critical thinking ability is significant after the given PBL model with STS approach by category increase was in medium in both classes.

With the online learning model of PBL, students face the exact problem in daily life. In addition to that, with STS approach issue that is authentic can be associated with technologies that exist in society's life. By learning the online model of PBL with the STS approach can improve students' critical thinking ability. Students can investigate the problem, interpret content associated with problem, analyze the causes and effects of a problem, evaluate the problem's process, and conclude the problem's results. Because can say that critical thinking ability is an ability that essential in problem-solving. The results are in line with the invention Suastra (2019) that the application of the model PBL provides the effect of solving the problem. The critical thinking ability is much better that conventional learning. Besides that, Agustina (2020), finding that there is influence of the model PBL to increase the critical thinking ability on each indicator. Another study conducted by Afni (2014) found differences in students' critical thinking ability between learning with STS approach and learning without STS approach. The research is also supported by research earlier by Muhibbudin (2019), finding that the STS approach can improve the students' critical thinking in learning physics.

Based on the results of independent ttest in "Table 7", there was a consistent increase in the critical thinking ability of high school students. It means online learning PBL model with STS approach effective to improve students' critical thinking in high school. The results of the research are relevant to the research by Laksono (2018), who find that the implementation of the PBL model has a quality better than the model of learning $5 \mathrm{M}$ in improving the critical thinking ability and ability to thinking science. In addition to the study of others performed by Puspita (2019), the learning-based problems, the ability of 
students in terms of critical thinking as analyze, interpret, evaluate, and inference further increased. It can occur due to PBL model is learning that using issue as a context of learning to develop a multidisciplinary, including the critical thinking ability.

\section{CONCLUSION}

Based on the results and data analysis in this research, the online learning PBL model with STS approach in the Global Warming topic was effective for improving the critical thinking ability of high school students. Based on the results of the research, students' critical thinking were significant at $\alpha=5 \%$ with an average score of $\mathrm{n}$-gain in category medium and consistent in both classes.

\section{REFERENCES}

Afni, N., Khairil, \& Abdullah. (2014). Penerapan Pendekatan STM (Sains Teknologi Masyarakat) Pada Konsep Pencemaran Lingkungan untuk Meningkatkan Hasil Belajar dan Kemampuan Berpikir Kritis di SMA N Wira Bangsa Meulaboh. Jurnal Biotik, 2(2), 77-137.

Aweke, S. (2017). The Effect of Problem Based Learning (PBL) Instruction on Students' Motivation and Problem Solving Skills of Physics,. ISER. 13(3), 857-871.

D H Putri, Risdianto, E., \& Sutarno, S. (2017). Pre-Service Physics Teachers' Perception toward Hands-on Lab Activity and 21st Century Skills. International J. Phys. Conf Ser. 895 012015 . doi:10.1088/17426596/895/1/012015

I B Nasution, W Liliawati, \& L Hasanah. (2019). Effectiveness Problem-Based Learning (PBL) with Reading Infusion Strategic to Improving Literacy for High School Students on Topic Global Warming. International J. Phys, Conf.
Ser. 1280 052013. doi:10.1088/17426596/1280/5/052013

Kurniasih, Imas, \& Berlin, S. (2015). Ragam Pengembangan Model Pembelajaran. Yogyakarta: Kata Pena.

Laksono, E. W., Suyanta, \& Rizky, I. (2018). Problem-Based Learning Implementation to Develop Critical Thinking and Science Process Skills of Madrasah Aliyah Students in Yogyakarta. International J. Phys.: Conf. Ser. 1097012059.

Muhibbudin, Sari, I. W., \& Mursal. (2019). Science Technology Society Approach Application on Students Literacy and Process Skills of Science to Study Dynamic Fluids. IJAEDUInternational E-Journal of Advances in Education, $V$.

Nasution, I. B., Liliawati, W., \& Hasanah, L. (2019). Effectiveness Problem-Based Learning (PBL) with Reading Infusion Strategic to Improving Literacy for High School Students on Topic Global Warming. International J. Phys, Conf. Ser. 1280052013.

OECD. (2018). Programme for International Student Assessment (PISA). Retrieved from http://www.oecd.org/pisa/PISA2018-Indonesia.pdf

P21. (2019). Framework for 21st Century Learning. The Partnership for 21st Century Learning. Retrieved from http://static.battelleforkids.org/docume nts/p21/P21_Framework_Brief.pdf

Pengelola Web Kemdikbud. (2020, Maret). Pembelajaran di Rumah Jangan Hanya Fokus pada Akademik, Ajarkan Anak Tematik tentang Covid-19. Retrieved from https://www.kemdikbud.go.id/main/blo g/2020/03/pembelajaran-di-rumahjangan-hanya-fokus-pada-akademikajarkan-anak-tematik-tentang-covid19 
Puspita , A. S., \& Aloysius, S. (2019). Developing Student's Critical Thinking Skills Through Implementation of Problem Based Learning Approach. International J. Phys, Conf. Ser. 1241 012020.

Putri, D. H., Risdianto, E., \& Sutarno, S. (2017). Pre-Service Physics Teachers' Perception toward Hands-on Lab Activity and 21 st Century Skills. IOP Conf. Science Journal of Physics.

Risnanosanti, Susyla, D., \& Syofiana, M. (2019). Developing Students Critical Thinking Ability Through Lesson Study. International I. Phys, Conf. Ser. $1320 \quad 012005$. doi:10.1088/17426596/1320/1/012005
Rusmansyah, Yuanita, L., Ibrahim, M., Isnawati, Rizkiana, F., \& Kusuma, A. E. (2020). Effect of Scientific Critical Thinking Model to Train Critical Thinking Skills and Students SelfEfficacy. International J. Phys, Conf. Ser. 1442012015.

TJ Syarifah, B Usodo, \& Riyadi. (2019). Student's Critical Thinking Ability with Higher Order Thinking Skills (HOTS) Question Based on SelfEfficacy. International J. Phys, Conf. Ser. 1265 012013. doi:10.1088/1742$6596 / 1265 / 1 / 012013$ 